\title{
1. The subjects and objects of EU law: exploring a research platform
}

\author{
Samo Bardutzky and Elaine Fahey*
}

\section{INTRODUCTION}

The words 'subject' and 'object' are an important part of the lexicon of Western philosophy, social sciences, humanities, and also law. The dichotomy and the relationship between the subject - the knower, the thinker - and the object - what the knower knows and the thinker thinks about - play a central role in the understanding of knowledge and society. The richness of the term 'subject', whether referring to the politico-legal, philosophical or a human being, illustrates the appeal of this framework to different fields of study. The notions of subject and object belong also to the classical vocabulary of the positivist or doctrinal study of law, especially public international law (PIL). Subjects form an unavoidable part of every contemporary international law treatise. But it is not at the heart of contemporary analysis of European Union (EU) law and policy.

The specific origins of EU law were framed by the Court of Justice (CJEU) by redefining its subjects, in its construction of the EU founding treaties, in a foundational decision in the 1960s, discussed in detail herein. However, for whatever reason, we argue there has yet to be sufficient engagement with these notions in EU law. This book explores whether the logic, the nature and reach of EU law and policy can be persuasively captured by investigating its subjects and objects. Our main claim is that the lexicon of subjects and objects offers a platform to

* The authors wish to thank Faizah Patel and Angelika Braouzi for research assistance, Panos Koutrakos, Marios Costa, Kangle Zhang and David Seymour for comments, and the participants of this research project from 2014 to 2016 for discussions that helped shape this contribution. The authors are grateful for the support of the City Law School and of the Centre for Comparative and European Law of the University of Kent. 
capture and analyse three specific issues. These are: the transformations, crises and the external/internal nexus of EU law. This volume is structured so that the contributions and case studies are organised in one normative-theoretical part and three parts that correspond to these three elements, often overlapping or cross-cutting.

The introduction to the volume starts by discussing the subjects of EU law, their original framing by the CJEU in Van Gend en Loos and what we might call a 'conventional' meaning of the subject of EU law. It goes on to propose that the subjects of EU law could be captured by a different definition, one that does not rely on the idea of a subject as bearer of rights and duties and a politically and legally active participant in the legal system. By adopting a more critical understanding of the word 'subject', a broader spectrum of the subjects can be captured by scholarly analysis. Capturing a broader spectrum of the legal subjects, however, does not mean that their political capacity cannot be scrutinized. The introductory text continues on to describe the difficulty in defining the objects of EU law and proposes a taxonomy of the different approaches to this issue. It discusses objects of EU law as a question of jurisprudence and procedure and as a construct and considers the constitutional and the administrative approach to the question. The chapter refrains from passing a final judgment on the definition of the object of EU law and accordingly warns against drawing a sharp line between the subjects and the objects of EU law. This text argues that observing EU law from the perspective of its subjects and objects is an alternative to systemic approaches. It also harbours potential to capture and analyse the legitimacy gaps and omissions fostered by contemporary EU law, evident within the three areas of transformations, crises and the internal/external nexus of EU law.

The final section of this chapter aims to establish a connection between the introductory chapter and the contributions collected in this volume. It does so by presenting four sets of questions that were posed to the contributors to facilitate the identification of the three elements considered in the individual case studies (transformations, crises and external/ internal nexus).

\section{SUBJECTS OF EU LAW}

\subsection{The Original Framing of Subjects (and Objects) in EU Law}

The central claim on which this book is based is that the framing of its subjects and objects is an important element in the development and 
formulating of EU law. What we could call the 'original' framing of the subjects, the recognition by the Court of Justice of the European Union (CJEU) in its landmark judgment in Van Gend en Loos that the subjects of EU law are not only the Member States but also the individuals (nationals of the Member States), carries an importance of what is usually called constitutional character. ${ }^{1}$ Miguel Poiares Maduro described this move as a 'subjectivation' of the treaties: EU law has moved from the state-based interpretation of the treaties to the individual-based interpretation. ${ }^{2}$ In Daniel Halberstam's account, on the one hand Van Gend en Loos contained a 'radical [constitutional] disaggregation of the State', and on the other hand is the beginning of a 'normative [and democratic] recalibration of the Community system', a normative 'turn to the individual'. ${ }^{3}$ In absence of an external constitutional author for Europe that is often imagined in constitution-making, the reallocation of roles and redefinition of the Member States and the individuals in Van Gend en Loos is considered one of the first elements of 'Europe's piecemeal constitution'. ${ }^{4}$

By and large, the framing of subjects of EU law in Van Gend en Loos was a prelude to a drift of EU law from the logic of public international law (PIL). By authoritatively framing the subjects of EU law, the CJEU extracted it from the long-standing debate concerning the dichotomy between subjects (more so than objects) in PIL. There, the perceived

1 'The Community constitutes a new legal order of international law for the benefit of which the states have limited their sovereign rights, albeit within limited fields, and the subjects of which comprise not only the Member States but also their nationals': Van Gend en Loos v Nederlandse Administratie der Belastingen Case 26/62 ECLI:EU:C:1963:1; [1963] ECR 1, 12. De Witte, Bruno, 'The European Union as an International Legal Experiment' in de Búrca, G, and JHH Weiler (eds), The Worlds of European Constitutionalism (Cambridge University Press, Cambridge 2012) 19; de Witte, Bruno, 'EU Law: Is it International Law?' in Barnard, C, and S Peers (eds), European Union Law (Oxford University Press, Oxford 2014) 174.

2 Maduro, Miguel Poiares, We the Court - The European Court of Justice and the European Economic Constitution (Hart, Oxford 1998), 9.

3 Halberstam, Daniel, 'Pluralism in Marbury and Van Gend' in Maduro, MP, and L Azoulai (eds), The Past and the Future of EU Law: Revisiting the Classics on the 50th Anniversary of the Rome Treaty (Hart, Oxford 2008) 29. See also Halberstam, Daniel, 'The Bride of Messina: Constitutionalism and Democracy in Europe' (2005) 30 ELR 775, 777.

4 Halberstam, Daniel, 'Internal Legitimacy and Europe's Piecemeal Constitution: Reflections on Van Gend at 50' in Tizzano, A, J Kokott and S Prechal (eds) 50th Anniversary of the Judgment in Van Gend en Loos (1963-2013) (Office des publications de l'Union européenne, Luxembourg 2013) 116. 
redundancy of the subjects' formulation has brought about many alternative theorisations of the 'actors' of PIL. For example, it has caused some to argue for a reformulation from subjects and object to 'participants', ${ }^{5}$ so as to escape the so-called 'prison' of the distinction. ${ }^{6}$ The entire discourse of PIL has arguably operated as a fight for inclusion as regards subjects and objects. ${ }^{7}$

It is stated that many international lawyers agree what the subjects doctrine is without explaining it. ${ }^{8}$ One may note that, in PIL, the subjects doctrine has been argued to act as the 'clearinghouse' between sources and substance. ${ }^{9}$ It is a discourse perceived to be perpetuated by subjective or even 'old-fashioned' positivists. It has most famously ignited a debate on the place of non-state actors in PIL. Instead, some call for more elaborate conceptual tools to systematize the lexicon of non-state actors and their role played in contemporary international law. Yet whether the solution lies in 'relativizing the subjects' or 'subjectivising the actors' remains for some time open to doubt. ${ }^{10}$

\subsection{The Critiques of the Original Framing of the Subjects of EU Law}

What kind of a subject is the subject of EU law as framed in Van Gend en Loos? The Court does not offer an extensive reasoning for its redefinition of the circle of subjects and recognition of individuals as subjects of EU law. It relies on the finding that, first, that '[i]ndependently of the legislation of Member States, Community law [...] not only imposes obligations on individuals but is also intended to confer upon them rights which become part of their legal heritage'. ${ }^{11}$ Second, behind the Court's framing of the subjects is the fact that the Treaties have

5 Eg Higgins, Rosalyn, Problems and Process: International Law and How We Use It (Oxford University Press, Oxford 1994), referencing the Yale School.

6 Bianchi, Andrea, Non-State Actors and International Law (Ashgate, Aldershot 2009).

7 Bianchi (n.6).

8 See Alvarez, José E, 'Are Corporations “Subjects" of International Law?' (2011) 9 Santa Clara Journal of International Law 1; Clapham, Andrew, Human Rights Obligations of Non-State Actors (Oxford University Press, Oxford 2006).

9 Klabbers, Jan, '(I Can't Get No) Recognition: Subjects Doctrine and the Emergence of Non-State Actors' in Bianchi (ed.), Non-State Actors and International Law (2009) 55.

10 Bianchi, Andrea, 'Relativizing the Subjects or Subjectivizing the Actors: Is That the Question?' in Bianchi (ed.), Non-State Actors and International Law (2009) xi ff.

11 Van Gend en Loos (n.1). 
established institutions 'endowed with sovereign rights, the exercise of which affects Member States and also their citizens'.12 Lastly, the individual is also a subject as he is accorded political subjectivity in the sense of having a say in the decision-making of the then Community, or in the words of the Court, he is "called upon to cooperate in the functioning of this Community through the intermediary of the European Parliament and the Economic and Social Committee'.13

The quotes reveal the individual as what we refer to as a liberal subject. By liberal subject, we refer to the liberal tradition of understanding an individual person and the self. Being a subject in the liberal sense equals bearing a number of (legal) rights which enable the subject to participate in society and pursue his project of self-determination. ${ }^{14}$

The subject of EU law as revealed in the quotes from Van Gend en Loos is, on the one hand, a bearer of rights and duties, particularly the newly recognized EU law rights. On the other hand, it is the subject of a supranational political order, someone who 'cooperates in the functioning' of the Union. The liberal subject of EU law is 'legally freed from the constitutional confines of her MS and endowed with [...] an immediate "jurisgenerative" capacity at the supranational level'. ${ }^{15}$

The individual as legal subject of EU law is exposed to a set of expectations. The individual becomes a 'legal vigilante' (or 'Private Attorney General') of this legal order. ${ }^{16}$ By invoking rights and entitlements conferred upon him by EU law, before national courts, he participates in a decentralized system of enforcement of EU law, praised for its efficiency. ${ }^{17}$ The vindication of the individual's rights under EU law, which pursues his private interests, is utilized for the public interest of upholding EU law in relation to the Member State. ${ }^{18}$ Joseph Weiler's critique of the original framing of subjects and objects of EU law is based primarily on the inadequate democratic legitimacy that would be capable of supporting the transformation of the EU legal order and its relationship with Member State law that ensued from the introduction of

2 Van Gend en Loos (n.1).

Van Gend en Loos (n.1).

14 Hughes, Cheryl L, 'Reconstructing the Subject of Human Rights' (1999) Philosophy \& Social Criticism 49. Hall, Donald E, Subjectivity (The new critical idiom) (Routledge, New York and Abingdon 2004) 26-27.

15 Halberstam, Pluralism (n.3) 30.

16 Weiler, Joseph HH, 'Van Gend en Loos: The Individual as Subject and Object and the Dilemma of European Legitimacy' (2014) I.CON 96.

17 Weiler (n.16).

18 Weiler (n.16). 
direct effect and the recognition of the individual as a subject of EU law. ${ }^{19}$ For Weiler, this turns an individual citizen into an object rather than a subject of EU law. ${ }^{20}$ Yet, while one way to describe the expectations put upon liberal subjects of EU law is as 'instrumentalisation' or 'objectification' of the liberal subject, we explore whether these processes can be captured by a different understanding of what is the subject of EU law.

\subsection{Subjects Constituted by EU Law}

The proposal made here for such a different understanding is to look beyond the understanding of a legal subject as a bearer of rights and duties and someone who is active in the law-making process. The other dimension to which attention should be paid is that the (legal) subject is defined and recognized by the government and by the law. To apply the term used by Louis Althusser: the subject is constituted when he is 'interpellated'. Althusser's example of interpellation is the following: a person that turns around when called by the policeman on the street. ${ }^{21}$ The policeman, by hailing the passer-by, creates out of him a subject answerable to law, to the State or to the legal system..$^{22}$ The identity of Althusser's subject had been ascribed to him beforehand. The subject only recognizes himself in the call, by answering accordingly. ${ }^{23}$

The understanding of the subject as an 'interpellated subject' is helpful as it allows for a broad range of entities that can recognize themselves as subjects of EU law due to the fact that EU law constitutes them and ascribes an identity to them. Compared to the idea that EU law has two narrow categories of subjects as proclaimed by the CJEU in Van Gend en Loos, based on recognizing the subjects as members of these two categories of politically empowered bearers of rights, this alternative understanding bears the promise of a much wider platform. A wide range of different individuals and entities can find themselves constituted in this way by EU law. The fact that an individual person is not a citizen of an EU Member State does not mean that Union law cannot constitute

\footnotetext{
19 Weiler (n.16) $99 \mathrm{ff}$.

20 Weiler (n.16) 102.

21 Althusser, Louis, 'Ideology and Ideological State Apparatuses' in Althusser, Louis, Lenin and Philosophy and other Essays (Monthly Review Press, London 2001) 118.

22 Mansfield, Nick, Subjectivity: Theories of the Self from Freud to Haraway (NYU Press, New York 2000) 53.

23 Blunden, Andy, 'Althusser's Subjected Subject', accessed 27 January 2017 at home.mira.net/ andy/works/althusser.htm.
} 
him as a subject. Persons who are citizens of countries that are not Member States, or who are stateless persons, can find themselves constituted as asylum seekers, as long-term residents, but also as workers, family members etc.

At the same time, legal persons are a vast and important group of subjects of EU law. Despite the fact that the framing of subjects of EU law was triggered by a corporation, the reasons given by the court to a large extent refer to a citizen of a Member State as the 'new' subject of EU law that takes his place next to the Member State. A different understanding of what is a subject can of course lead to a conclusion that corporations are constituted (as subjects) by EU law as natural persons are. Undoubtedly, a vast body of EU law can be seen to regulate, ascribe identity and recognize legal persons. Other entities may be constituted or recognize themselves in this way vis-à-vis EU law - for example, subnational units or organs of the Member States. ${ }^{24}$

Two observations should be made. First, many of the examples given in the preceding paragraphs (workers, citizens etc.) may also be seen as subjects (or enjoying at least traces of subjectivity) in the meaning of the word that was discussed initially: subjects as bearers of (some) rights (or duties), or as entities who enjoy standing in different procedures of EU Law. Second, it is not only EU law and its subject that can be observed by understanding its subjects as constituted or recognized by law. Every legal system could be observed in this way, and this approach allows us to recognize the richness of different legal subjects that it constitutes. It would seem, however, that EU law might offer particularly fertile grounds for the approach where subjects are understood to be constituted by law. Despite limited competences, EU law touches upon a large number of suspects in very different ways, defining countless positions for them. Even if, in a more positivist meaning of the word, a corporation is 'constituted', and thereby furnished with legal personality under the law of a Member State, not under EU law, and even if EU citizens are EU citizens by nature of their citizenship of a Member State, this does not preclude us from observing the many different ways in which an identity is ascribed to these subjects by EU law. ${ }^{25} \mathrm{~A}$ different understanding of the

24 See Josephine van Zeben in this volume, as well as Fasone, Cristina, 'National Parliaments in the EU. From new subjects to usual objects?' presented at the workshop on Framing the Subjects and Objects of EU Law, City, University of London 6 May 2016 (on file with authors).

25 Alina Tryfonidou's contribution in this volume offers an insight into the complexity surrounding the fundamental mechanism of recognition of recognizing individuals as citizens of EU law by granting them Member State citizenship. 
term 'subject', one that does not rely on being a bearer of rights, is liberating in the sense that we do not need to focus on the rights and entitlements of the subjects in order to observe and describe a wide spectrum of those subjects. It also allows us to use the lexicon of subjects to think of law beyond the rights and entitlements. This gives the exercise of framing the subjects of EU law a strong descriptive dimension. By that we mean that by merely referring to an individual, a corporation, an entity or a State as a subject of EU law, we are putting forward a claim that this subject should enjoy rights, entitlements, standing within EU law, its procedures and decision-making processes.

\subsection{Subjects and Law}

But if we are to follow the proposal and adopt a wider concept of legal subject (one that looks beyond the meaning of bearer of rights) the question arises: in what sense are thus-constituted and recognized subjects of EU law still 'legal subjects'? We draw on Damjan Kukovec's insight in this volume that ' $[\mathrm{w}] \mathrm{e}$ are all constantly deciding and creating our social and legal life in every social setting' ${ }^{26}$ The power of a legal subject to decide goes beyond what is usually considered to be the power of a legal subject: voting, putting forward initiatives, litigating and so on. ${ }^{27} \mathrm{~A}$ subject acts within the law through a broad array of other actions - for example, purchasing an item from a shop or migrating to another country. These actions that can be performed by a legal subject are foreseen by the law and the law ascribes consequences to them. A subject of EU law, seen in this way, is 'always-already' a subject, practising acts through which he is recognized as a subject. ${ }^{28}$

A dimension of the legal subject that should not be overlooked is the subject's contribution to the understanding of law. The value in studying law using the lexicon of subjects and objects is that we can perceive 'subjects and objects of legal interpretation as equal partners in the constitution of the legal system'. ${ }^{29}$ Jack Balkin's account presents a call for a more balanced view of law, one in which it is not only the object (i.e. law, the legal doctrine, the legal system) that is studied, but also the

\footnotetext{
26 Damjan Kukovec in this volume.

27 See n.26.

28 Althusser (n.21) 117.

29 Balkin, Jack, 'Understanding Legal Understanding: The Legal Subject and the Problem of Legal Coherence' (1993) 103 Yale LJ 134.
} 
legal subject - the interpreter or the 'understander' of law. ${ }^{30}$ We find that a balanced role of both subjects and objects of law in observing the law is of particular pertinence in EU law - a legal system that is interpreted by a vast multitude of different entities, natural and legal persons, courts, judges, lawyers, governments etc., belonging to a number of different legal traditions, political and ideological orientations and economic circumstances. In the EU, these traditions, orientations and circumstances vary to a larger extent that in any national legal system. Our interest in the dimension of the subject of EU law as the interpreter of EU law, however, does not mean that we are prepared to overlook the political dimension of the subjects of EU law.

\subsection{Political Capacity of the Subjects of EU Law}

When observing its political dimension, the subject of EU law again reveals itself as ambiguous and versatile. Two aspects of this issue are discussed here to illustrate the complexity of the political capacity of the subjects of EU law. In this Section, we look at the legal sources. In the following Section, we observe the political capacity of the citizen as subject of EU law, recognizing it as a particularly salient case study in the political dimension of the subjects of EU law.

The EU Treaties constituted a variety of political subjects of the European Union. The drafters drew a distinction between representative democracy and participatory democracy, without clarifying the relationship without them, possibly creating tensions between the two approaches to democracy. ${ }^{31}$ But representative and participatory democracy are primarily distinguished as there are different circles of subjects drawn by the Treaties. The definition of subjects of representative democracy of the European Union resembles the original framing of subjects of EU law in Van Gend en Loos. It is the citizens that are represented in the European Parliament; and it is the Member States that are represented in the European Council and in the Council, and expected to be democratically accountable to their citizens (Article 10(2) TEU). ${ }^{32}$

30 Balkin (n.29). The work of Siniša Rodin is also an analysis of the subject as understander and interpreter of EU law, focused on the CJEU understanding and interpreting EU law. See Siniša Rodin in this volume.

31 Kutay, Acar, 'Limits of Participatory Democracy in European Governance' (2015) 21 (6) ELJ 803-818.

32 An illustrative example of the perception of the EU citizenship as endowing the subject with political capacity presented by Alina Tryfonidou: Chapter 8 of this volume. 
These are the subjects, whose 'involvement [has been] institutionalised through the EU's law-making process'. ${ }^{33}$ These circles of subjects also appear in other accounts, for example they are perceived by Jürgen Habermas as the subjects of constitutional change in the European Union. ${ }^{34}$

The subjects of participatory democracy are defined in a number of partly overlapping circles, with only some of the forms reserved for citizens, acknowledging representative associations as well as the civil society, and even reaching the widely defined universe of "parties concerned' (Article 11 TEU). This, of course, means that the circle of political subjects as constituted by the Treaties transcends the geographical or territorial boundaries of the Union, encompasses foreign or multinational corporations with considerable interest in the end result of the decision-making process of the EU legislature. The lexicon of subjects and objects can serve to identify cases where political capacity as enjoyed by the interested parties from non-EU countries can lead to access deficit between economic and non-economic subjects. ${ }^{35}$

A distinct class of political subjects of the EU, as 'constituted' by Article 12 TEU, are the parliaments of the Member States. Mentioning the national parliaments in the Treaties, a development introduced by the Treaty of Lisbon, is a great illustration of how expectations that EU law has from its subjects, and the identity it assigns to them, go hand in hand with the creation of formal rights and empowerment to participate in the political process. ${ }^{36}$

\subsection{Political Capacity of the Subjects and the 'Subjectification' of the European Citizen}

We turn for a closer examination to one of the categories of subjects of EU law that were 'originally framed' in Van Gend en Loos: the citizens of the Member States. The citizen of the EU Member States as subject of EU law is particularly worthy of attention here due to the complexity of this concept. The citizen as a subject is a particularly complex issue because of the political dimension of his subjectivity. The political capacity, as recognized by the Treaties, which was discussed in the

\footnotetext{
33 See Joseph Corkin, Chapter 5 of this volume.

34 Habermas, Jürgen, The Crisis of the European Union: A Response (Polity, Malden MA 2012) 35.

35 See further, Emilia Korkea-aho, Chapter 11 of this volume.

36 Fasone (n.24).
} 
previous section, is only one layer of the political dimension of the subjectivity.

Citizens of the Member States are not only EU citizens and subjects of EU law. In line with the understanding of 'subject' that we have outlined, we argue that they are constituted and defined also by their national legal systems. Competing legal claims of overlapping legal systems can be observed from the perspective of subjects as well.

Furthermore: individuals-citizens of Member States are 'subjectified'. That means that they are exposed to regulatory expectations, strategies and pressures that are exerted by government power. In this understanding of the subject, individuals are made subjects by a form of power, and this power 'categorises the individual, marks him by his own individuality, attaches him to his own identity'. ${ }^{37}$ The individual faces a 'double bind' as he is not only controlled by the government. The power to which he is exposed also causes his individualization, and he is individualized by the power, in procedures, imposed upon him, through which he understands himself. ${ }^{38}$ The understanding that a subject is constituted and shaped by the exercise of governmental power has been used in critiquing EU citizenship law as a progressive narrative. ${ }^{39}$ Marco Dani draws our attention to the conflict that can emerge between contradictory supranational and national regulatory strategies, signalling the erosion of a citizen as a constitutional subject. ${ }^{40}$

An additional layer has to be added to the already complex coexistence of the two identities of the subject that is at the same time subject of EU law and citizen of a Member State. EU law has been offered as an answer to the question of external effects of the Member State law on the citizens of other Member States who have no political capacity that they could exercise in relation to the making of this law but are nevertheless affected by it, and, in certain constellations, (part-) constituted by it as its 'quasi-subjects'. ${ }^{41}$

\footnotetext{
37 Foucault, Michel, 'The Subject and Power' (1982) Critical Inquiry 781.

38 Foucault (n.37) 785; Hall (n.14) 92.

39 See Dani, Marco, 'The Subjectification of the Citizen in European Public Law' (2015) EUI Working Paper LAW 2015/02, 1-2, accessed 27 January 2017 at hdl.handle.net/1814/34701.

40 See n.39.

41 See Joseph Corkin in this volume. See Michelle Everson in this volume for the critique of this perspective.
} 


\subsection{Transformations in EU Law}

We argue that the transformations that we have witnessed in EU law as the original framing of the subjects and objects to EU law, and everincreasing growth in the scope, relevance, sphere of application and reach of EU law, can also be depicted as two overlapping layers of the individual citizen's subjectivity beginning in the nineties. Firstly, through the judicial creation of the Francovich/Brasserie de Pêcheur doctrine of State Liability for failure to implement EU law; 42 and secondly, through the strengthening of the infringement proceedings with the introduction of financial penalties. ${ }^{43}$ The introduction of sanctions for the breach of EU law is a compelling example of how a certain transformation in EU law can be seen in different light depending on whether we observe it, on the one hand from the perspective of EU law as a legal system, and on the other hand from the perspective of the subjects of EU law.

From the former perspective, the introduction of sanctions can be hailed as the 'perfection' of EU law (stemming from lex perfecta - lex imperfecta dichotomy). ${ }^{44}$ From the perspective of the citizen of a Member State as subject of EU law with a political dimension of his subjectivity, strengthening EU law with sanctions can also translate into more intensive pressure on the subject that is the target of government strategies. If the financial loss as the consequence of a breach of EU law is intended to incentivize the national politics not to breach EU law, then the principal mechanism to achieve this is through electoral accountability of the national government, cascading the pressure to comply with the supranational regulatory strategy down to the individual subject - the taxpayer and voter. At the same time, enforcement of EU law in its current form exemplifies well the schism between the subjects of EU law and what is the political dimension of these subjects - their capacity to form political decisions in the Member State. If on the one hand observing financial liability of Member States through the definition of subject as constituted by government regulatory pressures reveals the role of the subject in the functioning of the enforcement system, on the other hand the CJEU and the doctrine perceive the infringement proceedings as

42 See, for example, Schütze, Robert, European Constitutional Law (Cambridge University Press, Cambridge 2012) 396.

43 Art.260 TFEU.

44 Baquero Cruz, Julio, 'Francovich and Imperfect Law' in Maduro, MP, and Azoulai, L (eds), The Past and Future of EU Law: The Classics of EU Law Revisited on the 50th Anniversary of the Rome Treaty (Hart, Oxford 2010). 
proceedings of an 'objective character' ${ }^{45}$ The Government of the Member State, standing before the CJEU attempting to defend the Member State from the accusations of infringement, is barred from raising any kind of 'subjective' defence that would link the failure to comply with EU law to the Member State's parliament, courts, or subnational units. ${ }^{46}$

\section{8 (In)Coherence of the Subject}

In Section 1.4, we posited that the quest for a balanced role of subjects and objects as equal partners of legal interpretation was an important feature of studying law by observing its subjects and objects. Accordingly, we argue that attention ought also be paid to the role of the subject. In Jack Balkin's words: 'instead of seeing legal coherence as a preexisting feature of an object apprehended by a subject, we should view legal understanding as something that the legal subject brings to the legal object she comprehends.' 47 However, if the contribution of the subject to the law and the subject's legal understanding is not to be overlooked, then we also cannot assume that the subject itself is coherent. ${ }^{48}$ In Balkin's account, where the legal subject is an individual person, this is largely because the subject is herself socially constructed. Transplant this idea into the study of EU law, and a broad spectrum of incoherencies of the subject reveal themselves. As an example: the citizenship of one of the Member States or the citizen as subject of EU law (or the person's residence in a certain Member State ...) would seem to be an important determinant of the subject's social construction that influences the subject's understanding of the law. Acknowledging the incoherence of the subject of EU law allows us to factor into our study of EU law, for example, the centre-periphery dynamics at work in EU law, as explored in this volume by Damjan Kukovec. ${ }^{49}$

45 See Lenaerts, Koen, Procedural Law of the EU (Sweet \& Maxwell, London 2006) 146.

46 Take the example of the Data Retention Directive, where Member States were threatened with fines or fined for the non-implementation of a directive that was subsequently found to be in violation of human rights (Commission $v$ Sweden (Case C-270/11) ECLI:EU:C:2013:339). The pressure of EU law on the political subject to not only accept but via parliamentary accountability contribute to compliance with EU law is in conflict with the subject's identity as a constitutional subject.

47 Balkin (n.29).

48 Balkin (n.29).

49 See Damjan Kukovec in this volume. 
The concept of the subject constituted by interpellation, introduced above in Section 1.3, can be conducive to understanding that the subjects are not all the same and that they are constructed in different ways. Through the lens of Althusser's theory of interpellation of the subject we can also observe how groups of subjects are constituted and defined. ${ }^{50} \mathrm{In}$ EU law, this can help us observe how subjects are interpellated and constituted through different roles: a subject is recognised and constituted as a worker, or as a family member. ${ }^{51}$

\subsection{The Subject and the Crises}

It is our claim that the platform of subjects and objects of EU law offers a valid starting point for the study of the crises that the European Union has faced in recent years. Indeed, this volume comes at a time when the Union's constitutional settlement and its law is presented with a number of challenges, including the emergence of illiberal regimes in some Member States and the implications thereof for the rule of law as a constitutional value and the arrival of a large number of refugees from Syria in Autumn 2015.52 The most recent in the series of challenges is the June 2016 decision of the voters in the United Kingdom that their country is to leave the European Union. ${ }^{53}$ The financial crisis, however, has so far seen the largest corpus of literature emerge attempting to analyse it within EU law and legal scholarship, mapping the changes in the constitutional landscape of the European Union and its law caused by the crisis and the responses to it. ${ }^{54}$ It would seem that the crises have

50 Zhang, Kangle, 'Border and Authority: Private Credit Rating in NeoLiberal Society', Paper presented at the Borders, Otherness and Public Law, 2016 Conference of the International Society of Public Law (19 June 2016) (cited with permission of the author).

51 See also, for example, the interesting discussion on the 'good citizens' and the 'bad citizens' in EU law. Loïc Azoulai, 'The (Mis)Construction of the European Individual: Two Essays on Union Citizenship Law', EUI Department of Law Research Paper No. 2014/14, accessed 28 January 2017 at ssrn.com/ abstract $=2515889,11$.

52 'From eurocrisis to asylum and migration crisis: Some legal and institutional considerations about the EU's current struggles, Editorial Comments' (2015) CMLR 1-14.

53 Craig, Paul P, 'Brexit: A Drama in Six Acts', Oxford Legal Studies Research Paper No. 45/2016, forthcoming in European Law Review.

54 See Menéndez, Agustín J, 'Editorial: A European Union in Constitutional Mutation?' (2014) ELJ 127-141. See also Dawson, Mark, and Floris de Witte, 'From Balance to Conflict: A New Constitution for the EU' (2016) ELJ 386. 
touched upon several different categories of subjects. Member States have stepped outside the Treaties on a number of occasions - as was confirmed, this was in compliance with EU law ${ }^{55}$ - to develop the responses to the crisis. What at first sight could be interpreted as an empoverment of the sovereign States has led to wide gaps between the creditor nations and the debtor nations. The political capacity of the individual citizen as subject of EU law has taken its toll. National decision-making in Member States where austerity measures have been imposed by the representatives of the lenders is a curious species of democracy without a choice. ${ }^{56}$ These diagnoses seem to call for a revisiting of the role of the subject in the crisis situation.

While it may be reliably observed that the pressures exerted on the subject by the government pursuing its regulatory strategies increase as the manoeuvre space of national decision-making narrows, it would seem that these processes have taken on new forms. Is there space for any political capacity of the subject within the broader frame of the subjectification pressures experienced by both categories of subjects with the political dimension, citizens/individuals as well as Member States? The contribution of Emilios Christodoulidis on the substitution of subjective choice and decision-making with the objective output requirements casts a shadow of doubt on this being possible altogether. ${ }^{57}$ Or, from the other perspective, where is the power now, in the new societas economica analysed by Michelle Everson in her contribution? Rather than the exercise of power from the sporadically conflicting supranational and national government, as we have observed pre-crisis, who is the source of the governmental pressures on the subject now, post-crisis? ${ }^{58}$

55 Ledra Advertising ltd and others (Joined Cases C-8/15 P to C-10/15 P) ECLI:EU:C:2016:701; C-370/12 Pringle, EU:C:2012:756.

56 As phrased by Commission President Jean-Claude Juncker, 'Il ne peut $y$ avoir de choix démocratique contre les traités européens.' Delaume, Coralie, Du traité constitutionnel à Syriza : l'Europe contre les peuples, Figaro, 2 February 2015. Or Germany's finance minister Wolfgang Schäuble: 'Elections change nothing. There are rules.' Hewitt, Gavin, 'Greece: The dangerous game', BBC News, accessed 27 January 2017 at www.bbc.co.uk/news/world-europe31082656.

57 Emilios Christodoulidis in this volume.

58 Michelle Everson in this volume. Recent ECJ case law confirms the 'informality' of the Eurogroup which indirectly leads to impossibility of judicial review of its decisions (Konstantinos Mallis and others (Joined Cases C-105/15 P to C-109/15 P) ECLI:EU:C:2016:702, para.49), echoing the words reported by the former Greek minister of finance Varoufakis: 'Eurogroup does not exist in law'. Lambert, Harry, 'Our battle to save Greece (Interview with Yanis Varoufakis)', 


\section{THE OBJECTS OF EU LAW}

\subsection{On Actors and EU Law}

The contributions to this volume understand an object of law predominantly in two ways. First, the object is whatever is regulated by law. ${ }^{59}$ Second, the object can also mean what the subject thinks, perceives or interprets. ${ }^{60}$ They are all nonetheless united in being actor-centric accounts. One practical difficulty in approaching a method to identify the objects of EU law is that there is no agreed definition of an actor under EU law. ${ }^{61}$ Instead, a sharp distinction is drawn between the masters of the treaties and those amenable to judicial review or those with legal personality - yet it does not inform the framing of EU law's objects. The grant of legal personality under EU law has been accorded on a wholly pragmatic rather than conceptual basis. ${ }^{62}$ Many new actors created in recent times are not technically institutional actors: for example, the European External Action Service (EEAS), the European Cybercrime Centre (EC3) or the European Public Prosecutors Office (EPPO). Instead, they are carved up in other ways, for example, in the case of the EC3 as 'desks' of other institutions, e.g. Europol. This does not appear to preclude their autonomous development. ${ }^{63}$ Formalist understandings of those who are the objects of EU law are thus unable to capture much about EU law. It lacks realism about autonomy and institutional behaviour.

What might be phrased as increased levels of role circularity is also of relevance to the issue of the objects of EU law not being assisted by its constituent definitions of 'actors'. For example, executive actors of the EU (e.g. the European Council or the Euro group, ECOFIn) increasingly

New Statesman, 13 July 2015, accessed 27 January 2017 at www.newstatesman. com/world-affairs/2015/07/yanis-varoufakis-full-transcript-our-battle-save-greece.

59 This perspective is arguably obscured by a different understanding of how subjects are defined and constituted by power, ideology, law, etc., introduced in Section 1.3 above, which allows us to 'reframe' and have a wide net which catches a wide circle of subjects.

60 As for example Rodin in this volume, or Balkin (n.29).

61 See Ruffert, Matthias, 'Personality under EU Law: A Conceptual Answer Towards the Pluralisation of the EU' (2014) ELJ 346.

62 See n.61.

63 Gatti, Mauro, 'Diplomats at the Bar: The European External Action Service Before EU Courts' (2014) 39 (5) ELR 664. 
impinge upon domestic politics, often significantly so. ${ }^{64}$ How do we account for this role circularity when we consider the subjects and objects of EU law? We seek to incorporate a broader perspective on actors in EU law and seek to look at those beyond or outside the analytical capture of EU law. ${ }^{65}$ Beyond individual actors per se as entities or objects, the taxonomy or typology of the objects of EU law necessitates further analytical method, to which this account next turns.

\subsection{Transformations of the Subject and Object: On Role Circularity}

As to the question of how we understand the term 'the objects of EU law' as a term of art, this project adopts the view that a range of analytical approaches warrant exploration. As outlined above, on a purely descriptive (or even 'empirical') analysis, the treaties reference a vast array of terms as to entities other than Member States in the treaties, citizens, third parties, interests, third countries, but do not employ the generic term of objects, or anything specific about 'others'.66 The limitations of such an empirical approach are thus rather straightforward. The challenge, we argue, lies in that there is an overt circularity at the heart of deciphering subjects and objects. This is principally because in various ways, the 'subject' that we write of includes 'Member States', 'state institutions' and 'individuals'. To an extent, they are all 'subjects', as has been demonstrated above. However, as we have also tried to show, the perception of a subject modelled on the free and autonomous

64 Puetter, Uwe, The European Council and the Council: New Intergovernmentalism and Institutional Change (Oxford University Press, Oxford 2014); Curtin, Deirdre, 'Challenging Executive Dominance in European Democracy' (2014) 77 MRL 1; de Waele, Henri, 'Strained Actorness - The "New" European Council in Theory and Practice' in Fahey, E (ed.), The Actors of Postnational Rule-Making: Contemporary Challenges of EU and Public International Law (Routledge, Abingdon 2015); Bovens, Mark, and Deirdre Curtin, 'An Unholy Trinity of EU Presidents? The Political Accountability of Post-Crisis EU Executive Power' in Chalmers, D, M Jachtenfuchs and C Joerges (eds), The End of the Eurocrat's Dream: Adjusting to European Diversity (Cambridge University Press, Cambridge 2016) 190.

65 Consider e.g. Jones, E, A Menon and S Weatherill (eds), The Oxford Handbook of the European Union (Oxford University Press, Oxford 2012) focusing upon 'personalities' Member State cleavages, Institutions and Member States as the 'typology' of actors in the EU in a multi-disciplinary context.

66 The Member States of the EU are empirically and explicitly the primary 'subjects' of the EU treaties, receiving more references than any other entity in the treaties: see our calculation as follows using Eur-lex and Curia databases (at the time of writing), with thanks to Faizah Patel also for her assistance. 
individual is not likely to cover a broad spectrum of EU law. The subject of EU law is not disenganged from its object cleanly via 'neat lines' in the treaties. ${ }^{67}$ Take also, for example, the treaties that constitute the EU. They are objects of subjective (i.e. among Member States, the subjects) agreements, but then take on an objective character over those same subjects. There are multiple objects of EU law who are also the subjects of EU law but not involved in its making, for example Norway or Switzerland, hence a construction of participation or active engagement is not necessarily instructive. To sidestep the formalism and positivism that we wish to escape, we may unintentionally fall back into another radical form of separation between 'subjects' and 'objects' and, in so doing, reproduce the legitimacy gap that we want to overcome.

Table 1.1 Empirical count of the subjects and other entities referenced in treaties

\begin{tabular}{lrc}
\hline Word & TEU & TFEU \\
\hline 'Citizens' & 14 & 5 \\
'Contracting parties' & 1 & 1 \\
'Member States' & 99 & 400 \\
'Subjects of the treaties' & 0 & 0 \\
'Subject of the treaties' & 0 & 0 \\
'Subjects of the agreements' & 0 & 1 \\
'Subject of an agreement' & 1 & 1 \\
'Third Parties' & 1 & 6 \\
'Third Persons' & 0 & 0 \\
'Third countries' & 5 & 45 \\
'Interests' & 13 & 21 \\
\hline
\end{tabular}

\section{3 (In)Coherence of the Objects of EU Law: On Taxonomies}

As a result, we assert that there is a significance to taxonomizing analytical methods as to the subjects and objects of EU law as part of our framing and reframing exercise. Strictly speaking, the objects of EU law remain more troublesome, more opaque and more multifarious than its subjects, even if a perfect or clear separation of them both might be

67 Taylor, Charles, Philosophical Arguments (Harvard University Press, Cambridge MA 1997) Ch 1, 'Overcoming Epistemology'. 
unsatisfactory. One method might be to consider approaching the question of the objects of EU law as a descriptive question of jurisdiction and procedure, which is of much contemporary significance in case law, heavily centred upon secondary law and specifically environmental and financial and banking regulation in its focus. ${ }^{68}$ Such an approach appears to run into difficulties with its singular emphasis upon territoriality in an era of law beyond the nation state, its definition of law and rules, its constructivist tendencies and its limited range of case studies qua fields of law.

A further alternative would be to matter-of-factly consider the objects of EU law as a construct, flowing from foundational jurisprudence warranting a broader methodology to engage with its contours. It is one which is commonplace in contemporary environmental law, EU taxation, banking and financial services law, EU refugee and migration law, data protection and EU competition law. ${ }^{69}$ Indeed, it is now a regular occurrence of EU law such that it is broadly agreed to have global reach. ${ }^{70}$ The claim of global reach is usually substantiated by its authors to the effect that EU policy documents and legislation regularly attempt to link the internal to the external in EU law and policy with much transparency, including more frequently mooting its extraterritoriality. EU politics also emphasizes the global ambitions of EU law as warranting exploitation. Yet this does not necessarily provide us with real analytical clarity as to the category of others, institutions, entities or countries which are the recipients or takers of EU law qua others.

A further method might be a constitutional analysis of the boundaries of the internal and external of EU law, reflecting upon the objects of EU law as a tangential issue within an analysis of competence. This is common in mainly external relations scholarship, focusing upon international agreements and secondary legislation and its overlap with the internal market. EU external action may 'lead' or even eclipse internal policy development 'outwards in', which is not necessarily obvious as a

68 See Scott, Joanne, 'The New EU Extra-territoriality' (2014) 51 (5) CMLR 1343; Scott, J, 'From Brussels with Love: The Transatlantic Travels of European Law and the Chemistry of Regulatory Attraction' (2009) 57 (4) AJCL 897.

69 See n.68.

70 See Bradford, Anu, 'The Brussels Effect' (2012) Northwestern Univ Law R 1; Fahey, Elaine, The Global Reach of EU Law (Routledge, New York and Abingdon 2016); Damro, Chad, 'Market Power Europe' (2012) 19 JEPP 682. 
matter of EU law. ${ }^{71}$ For example, certain international agreements entered into by the EU have acted as the catalyst for internal EU legislation. The EU-US Passenger Name Records Agreements and EU-US Transatlantic Financial Tracking Programme (TFTP) (Swift) Agreement have triggered the development of comparable internal EU legislative proposals. ${ }^{72}$ This analysis is mostly conducted from the perspective of competence and a discussion of the role of the Court of Justice as to its constitutional significance, with a small ' $c$ '. ${ }^{73}$ Yet what the precise elements of the objects of EU law are now is not discernible from this. There is also little by way of case law in this area despite the analytical style here which is predominantly 'court-centric'. Contrasting approaches adopted here in this vein but broadly within this genre are adopted by Corkin in this volume (as to transnational constitutional law and the EU as a political community). ${ }^{74}$

A more concrete approach might be to reject the constitutional character of such an analytic method and to focus upon the question of the objects of EU law as one requiring an administrative approach. From primary law to secondary law and the plethora of administrative instruments deployed in the treaties, they raise a question as to the evolving nature of their scope beyond the EU and its territories, beyond existing partners and deliberately embed an ambiguity as to the ends of EU law. For example, Art.11(3) Treaty on the European Union (TEU) provides that the Commission is obliged to consult in its administrative rulemaking with 'the parties concerned', a phrase that appears to encompass stakeholders irrespective of their country of origin and which is interpreted broadly in EU policy documents. As the accounts of Vianello and Korkea-aho will explore, many EU administrative decisions are addressed to individuals or legal persons in third countries and there are also many obligations under EU law to initiate coordination or to monitor third-country conditions or international progress. The Ombudsman has significantly expanded the remit of her role in internal relations through conducting extensive analysis of the transparency as to third-party

71 Cremona, Marise, 'EU External Relations: Unity and Conferral of Powers' in Azoulai (ed.), The Question of Competence in the European Union (Oxford University Press, Oxford 2014).

72 See Fahey (n.64), Ch.2.

73 Cremona (n.71); Eeckhout, Piet, The European Internal Market and International Trade - A Legal Analysis (Oxford University Press, Oxford 1994).

74 See also Fasone (n.24). 
interests in EU law. ${ }^{75}$ These administrative approaches to the 'others' of EU law appears centrally focused upon EU external relations and environmental law. This is evident in the approaches adopted by Vianello and Korkea-aho in this volume as to EU Administrative and Environmental law.

A further complexity to that approach might suggest that administrative law approaches are themselves limited normatively and their innocuous character creates expectations and consequences which are non-innocuous for third countries and individuals. The question then arises less as to who the objects of EU law are but rather how they are treated. The Treaty of Lisbon makes clear that the Union, when acting on the international scene, shall not only promote the rule of law but shall also respect it in the development and implementation of its external action. ${ }^{76}$ However, as Vianello will argue in this volume, this obligation requires redefining the actorness of the EU in its relations with third countries as well as the actorness of the third countries themselves. Still, the approach of the EU must be gauged by a standard and the most frequent reference point in EU law for conduct is in the form of equal treatment or non-discrimination and respect for fundamental rights. We argue that such an approach has a distinguished pedigree at the heart of understanding the evolution of EU law beyond a customs union into a more sophisticated supranational project but yet does not necessarily offer clear answers. For example, in contemporary times, much debate in the context of the TTIP negotiations rests upon the treatment of foreign investors under EU law. Examples of this approach might be evident from the case studies conducted in this volume respectively by Poli (on restrictive measures and the broadening range of objects of EU law, rendering them subjects) and Velluti (on the objects of the EU's conditionality in its trade relations with respect to labour rights).

Yet the lack of a perfect fit in terms of a method (empirical, jurisdictional, constructivist, constitutional, administrative or equal treatment based) need not necessarily cause us concern. Rather, we argue that our project proposes a clearer taxonomy of the range of applicable approaches, many of which are evidenced in this book within individual case studies. They remind us of the importance of pushing out the

75 Regulation (EC) No 1049/2001 of the European Parliament and of the Council of 30 May 2001 regarding public access to European Parliament; Transparency of the Transatlantic Trade and Investment Partnership, Decision of 6 January 2015, accessed 27 January 2017 at www.ombudsman.europa.eu/en/ cases/summary.faces/en/58670/html.bookmark.

76 See Ilaria Vianello in this volume. 
barriers of method that cause us to exclude case studies, lose sight of contemporary significance or overlook the intellectual elephant in the room' (by which we could mean the role of the CJEU in EU law).

\section{THE SUBJECTS AND OBJECTS AS A METHODOLOGICAL FRAMEWORK FOR EU LAW}

\subsection{A Narrative for Transformations and Crises}

The exercise of framing methodologically and reframing substantively the subjects and objects of EU law is thus motivated by a concern for how to address legitimacy issues of EU law arising from the manifold role circularities prevailing. This is not a new concern, but we suggest that it is its most fundamental. The primary interest here is in social legitimacy of EU law in light of the transformations of EU law that we observe, and a subjects-objects relationship that can no longer rely upon output legitimacy so as to overlook social legitimacy concerns. ${ }^{77}$ Social legitimacy is a subjective measure; it is based on the subjects and their acceptance of the political regime on a deeper level than merely the popularity of the institutions etc. ${ }^{78}$ It stems from the subject's belief that the action, rule or system is morally or legally legitimate. In that sense, it is an elusive task to look for ways in which the legal system can be changed in order to foster its own social legitimacy. We claim, however, that there is an essential prerequisite for the legal system to obtain acceptance from its subjects. It is to recognize the contribution of the subjects' legal understanding rather than rendering the subject's input into the object of legal understanding invisible. ${ }^{79}$ We focus upon an inquiry into the relationship of the legitimacy of EU law on the one hand and the plurality of different actors, actions and rules as well as the relationships between them on the other hand. We thus seek to address through methodology the question of legitimacy in a way which deals realistically with coherence. We thus argue that structural normative coherence is possible between the subjects and objects of EU law.

77 Weiler, Joseph HH, 'Europe in Crisis - On "Political Messianism", "Legitimacy" and the "Rule of Law"' (2012) Singapore Journal of Legal Studies 248.

See n.77.

Balkin (n.29). 


\subsection{Looking Beyond a Systemic Understanding of EU Law}

We intentionally and consciously seek to side-step a systemic understanding of EU law, which we argue is prevalent in contemporary scholarship. Systemic ordering forms the intellectual basis for the most prominent $r e$-engagements in contemporary literature with the development of both transnational legal orders and EU law as discipline. ${ }^{80} \mathrm{We}$ suggest that systemic understandings of legal orders or ordering offer little to address the social reality and social acceptance problems of contemporary EU law. We argue that systemic understandings of EU law have a particular circularity to them. ${ }^{81}$ Systems-based understandings of EU law engage well with its complex multi-level structure and its living components, less so its substantive legitimacy issues. ${ }^{82}$ Contemporary theorizations of transnational legal order give systems-based analysis significant precedence. Systemic understandings of EU law appear to reify its chaos, anarchy, unpredictability and irregularity. What has systems theory done for law-making beyond the nation state? We opine that order-based analyses are both over- and under-inclusive. This lack of focus upon the individual is considered in much detail by various case studies in this volume. Systems-based theorizations are striking for their lack of focus upon the individual. Moreover, we contend that the CJEU has rejected a Hartian understanding of EU law in its core case law through its embrace of the subject-object dialectic. This remains its defining characteristic which we argue warrants still further development as a future research agenda.

\section{THE SUBJECT-OBJECT RELATIONSHIP AS A PLATFORM FOR EU LAW}

We thus argue that the subject-object relationship provides a particularly useful platform in its lexicon for those grappling with key issues of EU

80 See, for example, Halliday, Terence C. and Shaffer, Gregory, Transnational Legal Orders (Cambridge University Press, New York 2015) ch.1; Dickson, J, and P Eleftheriadis (eds), Philosophical Foundations of European Union Law (Oxford University Press, Oxford 2012), ch.1, both citing inter alia Luhmann and Teubner.

81 See also de Witte (n.1).

82 E.g. Teubner, Gunther, Critical Theory and Legal Autopoiesis: Perspectives of Societal Constitutionalism (Manchester University Press, Manchester 2016). 
law and policy today. We argue that it supports the normative motivations underpinning the project, specifically to include the many omissions from contemporary EU law as set out in this project, and operates as both a powerful framing and reframing tool in this way. It has both a vagueness and flexibility - which we acknowledge and embrace - which is important in so far as it is malleable and broadly applicable across subject streams and sub-disciplines. It accordingly enables us to look beyond primary, secondary law and case law so as to look critically at broader developments, through a philosophically-minded lens which acts as a check upon context, real and actual framing and effects. By acting as an enabling device so as to explicitly articulate a broader context, the subjects-objects formulation thus bring transparency to these broader shifts that are charted by various authors. It is both a lexicon and methodology and shifts discourse in its own way and is thus a vivid narrative device. We accept the logic of the simultaneous and symbiotic status of subjects and objects as an integral part of its theoretical structure and contend that it sits on all fours with the theoretical foundations of EU law.

This book attempts to show how the transformational character of EU integration can be accurately captured through the specific study of the transformation of subjects and objects and, vice versa, in a set of particular case studies on its active and dynamic quality. The study of subjects and objects also enables us to consider the internal/external nexus of contemporary EU law with greater precision and transparency. It facilitates our specific study of territory, neighbourhood and the expanding portfolio of those captured by sanctions, regulation and conditionality all under one theoretical 'roof'. Most significantly, we aim to step back holistically and examine the EU project and its unfolding series of crises through the lens of subjects and objects. We can uncover much about exclusions and inclusions, legitimacy and regulatory capture in this period. As a result, we reach the width and depth of EU law. The lexicon of subjects and objects in particular forces a more specific 'take' upon who is most active and passive here, who is left out and the place of markets, risk and uncertainty in our methodological framing.

\section{FORMAT OF THIS BOOK}

This book is divided into four distinct parts. The first is the most theoretical and seeks to consider the normative motivation and theoretical underpinnings of the subject-object discourse (Part I). The next section considers explicitly the idea of transformations from subjects to objects 
and objects to subjects, thereby capturing the dynamic character of the subject-object relationship (Part II). The sections thereafter consider the expansive quality of the subjects and objects relationship as to EU law and focus upon the external dimension of EU law and its link to the internal, with respect to the range of actors, entities and subjects that it encompasses, excludes or captures (Part III). This leads to the final section, which seeks to approach methodologically the question of how we understand EU crises. It considers who has been the subject and object of EU measures. Who has been excluded? How do we frame discourse on crises? Who is most active or passive? How can we better capture a legitimacy narrative? (Part IV).

In each section, the authors were asked to address some of the following questions, where possible and applicable to their account. Thus, in Part I, all authors were asked to consider the following:

i. Is the dialectic between subjects and objects useful to capture EU law? Does it provide you with a platform, a means or simply a lexicon to describe your case study?

ii. Does reaching for the lexicon of subjects and objects help not only to present your theoretical contribution or case study, but also to advance your cause or normative claim within your case study?

iii. Do you find the subjects/objects to be more useful as a lexicon with which integration can be described or as a narrative device (with the flexibility to present a narrative holistically)?

iv. Is EU law expansionary in its objects and limiting in its subjects generally? Or expansionary as to both?

v. Are the PIL origins of EU law easily forgotten or practically overlooked?

vi. Do you agree that the lexicon and method of subjects and objects can be a reframing exercise of how we understand EU law?

vii. What is the most powerful motivation to re-orientate or reframe the subjects and objects of EU law?

In Part II, contributing authors were asked to consider the following questions:

i. Articulate if there is a transformation which is central to your case study or a by-product of it. Do you judge this transformation as positive?

ii. Who or what undergoes the transformation in your case study or account? Are there several such active/dynamic elements? 
iii. Can the expansion of the scope, reach and relevance of EU law since the milestone in Van Gend en Loos be described as a transformation in the position of EU law's subjects and objects? Particularly in your case study?

iv. Is the transformation in your case study best described as a shift from subjects to objects (or objects to subjects) or as a change in the quality/meaning/position of the subject or object?

v. Does the application of the lexicon of subjects and objects to your case study or abstract considerations lead you to identify an omission of EU law? If so, is this omission a legal issue, a socio-political issue or something else?

vi. How, in particular, are individual persons visible in your account of subjects and objects of EU law?

vii. Are citizens both subjects and objects through national and supranational dichotomies?

viii. Which is more common, shifts from objects to subjects or subjects to objects?

ix. Is a discussion of objects possible without subjects? Could you exclude citizens from your account?

$\mathrm{x}$. Does the transformational quality/active/dynamic quality of subjects and objects assist your case study?

xi. Articulate what the subjects/objects distinction lends to your account.

xii. Is this account partially/wholly/substantially transformational?

Authors in Part III were asked to consider the following questions:

i. Can you articulate the internal/external nexus of EU law in your case study?

ii. How does subject/object align to the internal/external?

iii. Are objects 'external' only?

iv. How do objects become subjects in EU external relations law? Who is involved? Who is most active or instrumental?

v. What is the role of fundamental rights in the shift between subjects and objects here? How do you frame fundamental rights?

vi. Do exclusions from rights to fair procedures/legitimate explanations cause greater challenges for objects or subjects? What makes you form this judgement? Do primary or secondary sources assist you most? What hierarchical structure of norms assist you in your analysis (please be explicit if possible)?

vii. What is external about your case study? Is this well understood or accepted, do you think? 
viii. How does the subject/object dynamic change your case study? How would it tell it without it or what added value does it present to you?

And in Part IV, authors were asked the following set of questions:

i. Do the crises need to be understood holistically (e.g. by approaching the different crises in the EU - financial, migrant, Brexit - in order with a common understanding of a crisis) to describe the transformational shift from subject to object? Is a discrete case study, e.g. migration or the euro crisis, sufficient?

ii. Have crises generally changed the subjects and objects of EU law? Why? How?

iii. Does the subjects/objects dialectic capture well/wholly/partly an exclusion from the crises?

iv. What does the subject/object lexicon add to your crises case study?

v. How does the subject/object dialectic assist your case study? Does it develop a legitimacy narrative better?

vi. Are citizens or individual persons the biggest victims of the crisis/crises in your case study? Does the relevance of citizens as subjects diminish in the crisis? Would you describe the citizens as objects as a result of the crisis in your case study?

vii. Is there an external dimension to the crisis that appears in your case study?

viii. If the crisis you develop has seen the multi-level form of the EU change, e.g. EU Executive impinges more upon national politics, is the 'subject' eroded? If so, how do you understand the active quality of erosion?

We next invite the reader to reflect upon these broad areas of inquiry in the sections herein, followed by our Conclusions thereafter. 
Samo Bardutzky and Elaine Fahey - 9781786435743 Downloaded from PubFactory at 04/26/2023 02:19:27PM via free access 